\section{Scleral Contact Lenses for Treatment of Ocular Surface Disorders: A Narrative Review}

\author{
Ramkishor Sah* and Jeewan S Titiyal \\ Dr. Rajendra Prasad Centre for Ophthalmic Sciences, All India Institute of \\ Medical Sciences (AlIMS), Ansari Nagar, New Delhi-110029, India
}

\begin{abstract}
Scleral lenses have been in the origin of contact lenses back in 1880 , when the pioneers did the first glass contact lenses. With the advent of highly oxygen permeable materials and the increasing need for advanced solutions for severe ocular surface disorders has produced the driving pressures for a great amount of different contact lens designs to be available. The ocular surface disorders such as Primary Ocular Ectasia, Corneal Transplant, Ocular Surface Diseases, Aphakia, Myopia, PMDs, Keratoconus, Dry Eyes, Post-Refractive Surgeries and Trauma can be treated with slceral lenses. This literature reviewed support the effectiveness of scleral lenses. The main outcomes of the major trials published in peer-review journals obtained from PubMed, Google Scholar, Research Gate \& CORE search engines have been reviewed and presented in a summarized structure in order to a better understandings of modern scleral lens.

However, considering the physiological implications of these lenses and the potential interaction with seriously compromised eyes, it is pertinent to review the main advantages and drawbacks of these devices and how to overcome them from the morphological point of view to enrich fitting process and the physiological point of view to improve medium and long-term tolerance.
\end{abstract}

Keywords: Corneal ectasia; Diadenosinetetraphosphate (Ap(4)A); Dry eye; Irregular cornea; Keratoconus; Matrix metallopeptidase-9; Ocular surface disease; Ocular surface homeostasis; Scleral contact lens; Stevens-Johnson syndrome

\section{Introduction}

Scleral contact lenses have been in the origin of contact lenses back in 1880 when the pioneers did the first glass contact lenses. These lenses have a back history about years of century with available option for ocular and vision correction [1]. A new introduction of

*Corresponding author: Ramkishor Sah, Dr. Rajendra Prasad Centre for Ophthalmic Sciences, All India Institute of Medical Sciences (AlIMS), Ansari Nagar, New Delhi-110029, India, Tel: +91 9999777632; E-mail: ramkishorsah@ yahoo.com

Citation: Sah R, Titiyal JS (2021) Scleral Contact Lenses for Treatment of Ocular Surface Disorders: A Narrative Review. J Ophthalmic Clin Res 8: 086.

Received: June 27, 2021; Accepted: July 09, 2021; Published: July 16, 2021

Copyright: ( 2021 Sah R, et al. This is an open-access article distributed under the terms of the Creative Commons Attribution License, which permits unrestricted use, distribution, and reproduction in any medium, provided the original author and source are credited.
High Oxygen Permeable (HOP) materials and mounting the need for advanced solutions for severe ocular surface disorders have produced the driving pressures for a great amount of different contact lens designs to be available [2]. These lenses have become an integral part of the specialty contact lens practice. Tangible Hydra-PEG (Hydra Poly-Ethylene-Glycol) developed by (Tangible Science, LCC, Menlo Park, CA, USA) is a breakthrough custom contact lens coating designed to solve the problems of discomfort and dry eyes. It is Polyethylene Glycol (PEG) based polymer mixture that is clear, water-based coating that is permanently bonded to GP and hybrid contact lenses. It covers lenses in a smooth wet layer designed to maintain natural tear film, composed of $90 \%$ water content and resistant to protein \& lipid deposits, which can increase your comfort and wear time [3].

Now a day practitioners can draw from a variety of scleral lenses to best fit their patient's contact lens needs. The new development of materials with high gas permeability together with various advance technology innovations in the lens design and manufacturing of scleral lenses has open new prospective for their use. These lenses available today have the potential to really improve the lives of our patients not only by helping them see better but also providing all day comfort and there are instances when visual rehabilitation has only been successful with scleral [4]. Therapeutically, scleral contact lenses are the latest options available for treating dry eye disease (DED) [5]. Advancements in lens manufacturing technology, lens materials and fitting techniques have expanded the capabilities of treating those patients with compromised corneas [6]. Several publications report on long-term outcomes and success in managing moderate to severe dry eye disease with scleral lenses. According to the tear film and ocular surface society (TFOS) Dry Eye Workshop DEWS II report, those who are symptomatic with signs of ocular surface disease may benefit from scleral lenses and show improvement in corneal punctate staining \& filamentary keratitis. In addition, the DEWS II report stated that those with neurotrophic keratitis and neuropathic pain may benefit from scleral lenses [7]. Ocular surface disorders such as dry eye disease, sjogren syndrome, limbal stem cell deficiency (LSCD), filamentary keratitis and exposure keratopathy are challenging to treat; following these cases scleral contact lenses may play key role in the management of these conditions. However, many patients with keratoconus, corneal ectasia and post-surgery are also associated with dry eye [6]. In addition to treating corneal irregularities, scarring and high astigmatism; the scleral lens's tear reservoir may also effective in dry eye [8]. Patients with severe dryness may require frequent replacement and may not be able to sustain full-time lens wear due to the severity of their condition [9].

The contradictory to popular perception, the large size and scleral bearing surface of scleral contact lenses can be beneficial in the management of certain ocular surface disorders $[10,11]$. Scleral lenses usually eliminate those above discomforts because they are classically fit with complete corneal clearance and only scleral bearing, while their large size ensures that there is minimal eyelid interaction. It also provides an alternative vision solution for those who have grown intolerant to corneal conventional contact lenses or for patients 
who have high amounts of residual corneal astigmatism [12]. In recent years the developments of scleral lenses have more options for patients to treat different ocular disorders. These lenses are being prescribed for the management of corneal irregularity, uncomplicated refractive error and ocular surface diseases [13]. Scleral lenses rank second only to corneal rigid gas permeable lenses for management of corneal irregularity, it generally considered after other medical intervention and before surgery for the management of ocular surface disease [14]. In addition these lenses can be successfully used in the management and protection of moderate to severe ocular surface disease (OSD), improve visual acuity in patients whose surface disease has compromised vision $[15,16]$. The purpose of this review is to summarize a new novel approach, future prospects for scleral lenses and contributes to their success with current clinical practices.

\section{Materials \& Methods}

The literature search was performed using following these headings \& sub-headings such as Scleral contact lens, Keratoconus, Irregular cornea, Corneal ectasia, Ocular surface disease, Dry eye, Stevens - Johnson syndrome, Ocular surface homeostasis, Matrix metallopeptidase-9 and Diadenosinetetraphosphate (Ap(4)A) or its combinations. The literature search included 67-publications from PubMed, Google Scholar, Research Gate \& CORE search engins have been reviewed.

\section{Indications}

The modern scleral lenses are indicated for several ocular conditions and can nearly always be fitted successfully. A scleral lens provides optical correction, mechanical protection, relief of symptoms and healing facilitators. It creates a neutralizing tear lens that corrects any corneal irregularities and it retains a pre-corneal reservoir [17]. In severe corneal distortion, which occurs in keratoconus and other corneal diseases are a major obstacle to the fitting of corneal contact lenses [18-20]. Inability to fit contact lenses is often due to a variation in the corneal bearing areas which make it impossible to achieve a satisfactory fit and can also result in subjective irritation. In these cases the successful fitting of high gas-permeability scleral lenses made of rigid fluoro-silicone-acrylate co-polymer with a $\mathrm{Dk}$ of $110 \times 10^{-11}$ $(\mathrm{cm} 2 / \mathrm{sec})(\mathrm{mlO} 2 / \mathrm{ml} \times \mathrm{mm} \mathrm{Hg})$ at $35^{\circ} \mathrm{C}$ was reported by Rabinowitz YS [21]. In general, most of the eye conditions for which contact lens correction is an option can be considered for scleral lenses if the wearer is experiencing problems with conventional lenses.

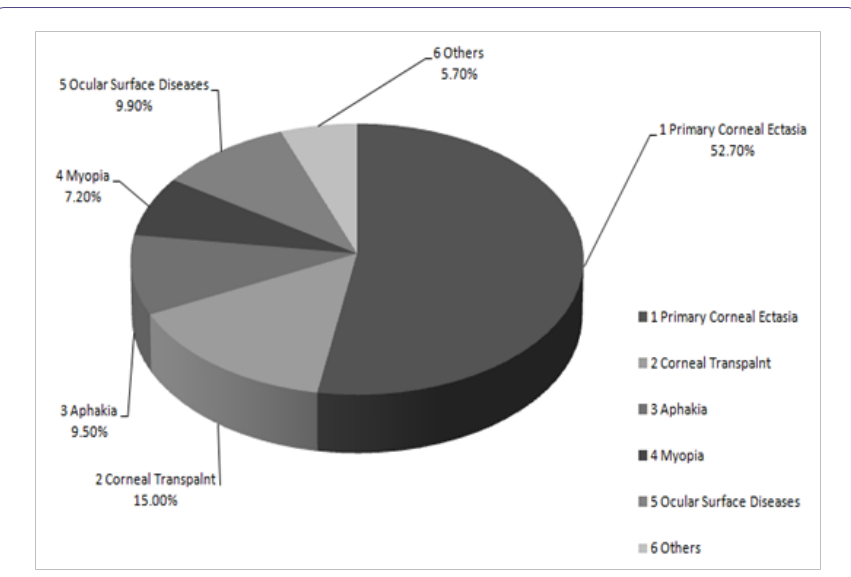

Figure 1: This reference data is collected from Moorefield and Oxford Eye Hospital. The above figure shows the major indications for scleral contact lens [20].
Scleral lenses should be considered especially in the following condition like Primary corneal ectasia (e.g. Keratoconus, Keratoglobus, Pellucidmarginal degeneration, Terrien marginal degeneration, Corneal dystrophies) and Advanced corneal ectasia \& Post-keratorefractive ectasia (e.g. Post-LASIK, Post-LASEK, Post-RK \& PRK, Corneal Transplant), Aphakia, Myopia, Ocular Surface Diseases (OSDs) and others i.e. Aniridia, Ptosis, Exophthalmos, Trichiasis, Entropion, Protective \& Therapeutic application as well as in drug delivery. The OSDs encountered can be categorized into two groups: first, those with mucosal disorder (an autoimmune disorder) create scars \& conjuctival inflammation that may lead to corneal involvement and second, primary corneal abnormalities with a normal conjunctival function [20,22]. Ocular drug delivery involves achieving therapeutic concentrations of medication at the ocular surface. This is traditionally achieved through eye drops, sometimes frequent dosing is necessary to achieve therapeutic concentrations. Unfortunately, frequent dosing is inconvenient, not cost-effective, and often leads to patient noncompliance. To overcome these limitations found in conventional eye drop treatment, novel delivery systems and devices have been explored. It is suggested that therapeutic lenses may be suitable for controlled and sustained drug delivery due to their extended-wear function and higher bioavailability than eye drop formulations [23] (Table 1).

\section{Classification \& Terminology}

In the past, the Scleral Lens Education Society (SLS) defined lenses based on their diameter and where they rest on the ocular surface. Scleral contact lenses are globally defined as lenses resting entirely on the sclera. These lenses are up to $6 \mathrm{~mm}$ larger than horizontal visible iris diameter (e.g. has up to $3 \mathrm{~mm}$ of bearing on the sclera on each side of the cornea) being further described as "mini-scleral" lenses. Lenses those extending beyond the $6 \mathrm{~mm}$ than the horizontal visible iris diameter are considered as "large scleral". Lenses resting partly on the cornea and partly on the sclera were known as "corneo-scleral" and finally, lenses resting entirely on the cornea were referred to as "corneal lenses". The new terminology to define scleral lenses removes the difference between mini and large lenses. All scleral lenses, regardless of size, are fitted to completely vault over the cornea and land on the conjunctiva, thus there is no need for distinction and the terminology can be simplified to "scleral lens" for all sizes of lenses. To this point, knowing that the scleral contact lens is resting on the ocular surface and that the conjunctiva conforms to the shape of the underlying sclera, the term scleral is kept on the basis of naming the lens by where it distributes its weight or bears on the ocular surface [25,26-29]. The different categories can be recognized to acknowledge the differences in lens fit and challenges. The difference apart from bearing area and location among the smaller \& larger diameter lenses is the amount of clearance that can be created underneath the central lens. The small diameter scleral lenses the tear reservoir capacity is typically small, while in the larger diameter scleral contact lenses the tear reservoir capacity is almost unlimited. All types of scleral contact lens designs have the ability to promote good apical clearance to some degree compared to corneal contact lenses, which can reduce mechanical stress to the cornea and is the major advantage of any type of scleral contact lens [26,29].

According to Scleral Lens Education Society, 2018 [27], the term scleral lens is used to describe the broad range of all large diameter lens modalities but if a specific lens type is referred to, then that terminology (e.g., corneo-scleral, full-scleral, mini-scleral and large-scleral) will be used (Table 2). 


\begin{tabular}{|c|c|c|c|c|c|c|}
\hline \multicolumn{2}{|c|}{ Irregular Cornea } & \multirow[b]{2}{*}{$\begin{array}{c}\text { High } \\
\begin{array}{c}\text { Refractive } \\
\text { rors }\end{array}\end{array}$} & \multicolumn{4}{|c|}{ Therapeutic } \\
\hline Primary Corneal Ectasia & $\begin{array}{l}\text { Advance Corneal } \\
\text { Ectasia \& Post-Kera- } \\
\text { torefractive Ectasia }\end{array}$ & & Mucosal Disorder & Corneal Disorder & Corneal Protection & Cosmetic \\
\hline $\begin{array}{l}\text { - Keratoconus } \\
\text { - Keratoglobus } \\
\text { - Pellucid marginal } \\
\text { degeneration } \\
\text { - Terrien marginal } \\
\text { degeneration } \\
\text { - Corneal dystrophies }\end{array}$ & $\begin{array}{l}\text { - Post-LASIK } \\
\text { - Post-LASEK } \\
\text { - Post-RK \& PRK } \\
\text { - Post-PK (Corneal } \\
\text { transplant) } \\
\text { - Post-corneal trauma } \\
\text { - Corneal scarring }\end{array}$ & $\begin{array}{l}\text { - Myopia } \\
\text { - Hypermetropia } \\
\text { - High astigmatism } \\
\text { - High power; leading } \\
\text { to decentration, } \\
\text { creating diplopia \& } \\
\text { prismatic effect }\end{array}$ & $\begin{array}{l}\text { - Dry eye } \\
\text { - Stevens Johnson } \\
\text { syndrome } \\
\text { - Sjogren syndrome } \\
\text { - Cicatricising ocular } \\
\text { pemphigoid } \\
\text { - Chemical burn } \\
\text { - Pterigium }\end{array}$ & $\begin{array}{l}\text { - Exposure keratitis } \\
\text { - Epithelial defects } \\
\text { - Epithelial dysplasia } \\
\text { - Neurotrophic keratitis } \\
\text { - Filamentary keratitis } \\
\text { - Drug delivery }\end{array}$ & $\begin{array}{l}\text { - Ocular surface } \\
\text { disease } \\
\text { - Pain relief } \\
\text { - Nerve palsy } \\
\text { - Keratoconjuctivitis } \\
\text { - Trichiasis } \\
\text { - Entropion } \\
\text { - Ptosis } \\
\text { - Persistent epithelial } \\
\text { corneal defects } \\
\text { - Graft vs. Host disease }\end{array}$ & $\begin{array}{l}\text { - Aniridia } \\
\text { - Iris coloboma } \\
\text { - Irregular Iris } \\
\text { - Microphthalmos } \\
\text { - Lagophthalmous }\end{array}$ \\
\hline
\end{tabular}

Table 1: The major indication of scleral contact lenses categorized on the basis of management $\&$ therapeutic applications in ocular surface disorders [2,24].

\begin{tabular}{|c|c|c|}
\hline \multicolumn{3}{|c|}{ Terminology \& Classification } \\
\hline Types of Lens & Sub-division & Bearing \\
\hline Corneal & - & Lens rests entirely on the cornea \\
\hline Corneo-Scleral & - & Lens rests partly on the cornea \& partly on the sclera \\
\hline \multirow{2}{*}{ Full Scleral } & Mini-scleral lens is up to $6 \mathrm{~mm}$ larger than HVID & \multirow{2}{*}{ Lens rests entirely on the sclera } \\
\hline & Large-scleral lens is more than $6 \mathrm{~mm}$ larger than HVID & \\
\hline
\end{tabular}

Table 2: The Scleral Lens Education Society (SLS) introduced an internationally recognized nomenclature for describing scleral lenses based on the resting zone area of the lens on the ocular surface, not on lens diameter [27].

\section{Lens design}

Scleral lenses have a special design that is much larger than a typical contact lens and a great tool to provide relief for patients. These lenses are large diameter that it extends beyond the limbus and crucially has its bearing surface on the scleral rather than resting on the cornea. It fits onto and is supported by the sclera, the white portion of the eye and creates a tear-filled vault over the cornea. It has its bearing surface on the sclera and is fitted with no or minimal corneal contact. They have their advantages too such as better fit and more comfort for patients [30]. They can provide retention of a pre-corneal tear reservoir for corneal hydration with total protection from the external environment, lid margins and eye lashes. They can relieve pain, prevent exposure keratitis and enhance epithelial healing. It also affords simultaneous optical correction of the irregular corneal surface and the rigidity of the material provides optical correction. These lenses are also a great tool in masking and correct the corneal irregularity that result from various corneal ectasia especially for patients who have failed in traditional corneal, piggyback or hybrid contact lens fit.

The anatomy, nomenclature and designs of the scleral contact lenses are based on the back scleral radius (BSR) and Total Diameter (TD) both are variables, which need to be kept constant for a range of Optic Zone Designs (OZD) in order to vary corneal clearance. The optic zone may be defined either by optic zone sagitta (OZS), acombinations of Back Optic Zone Radius (BOZR) and Back Optic Zone Diameter (BOZD) are used to vary to sagittal depth. The early design for the limbal zone was a trans-curve but more modern designs are aspheric. The importance of the Optic Zone Projection (OZP) is to achieve an ideal corneal clearance varied by altering the forward projection of the optic zone from the extrapolation of the scleral curve at its apex without reference to the BOZR or BOZD. The limbal zone is an aspheric curve and may be specified by projection from the extrapolation of the scleral plane at the edge of the optic [25,31-33] was conqueror of a first designer and fabricator of scleral lens by gas permeable materials, who reported the successful rehabilitation of patients with keratoconus. The introduction of this gas permeable material was revolutionary for scleral lenses and has led to the development of new and much improved lens designs being utilized today. This lens material has significant advances over the past 10 years, encouraging further consideration of their application to the scleral lens design in the rehabilitation of corneal disorders $[34,35]$. The material used in these lenses is a fluoro-silicon-acrylate co-polymer with very high oxygen permeability. The most recent development in this material takes place after approval of Food and Drug Administration with a various technologic innovations in the design and manufacturing of these lenses have opened new prospective for their use [36]. In addition the lens material, the thickness of a ScCL over the scleral zone must be between $0.50 \mathrm{~mm}$ and $0.80 \mathrm{~mm}$ and it depends on the diameter. The more usual range of diameter of ScCLs can be between $15-25 \mathrm{~mm}$, although impression lenses can be even larger. The $16 \mathrm{~mm}$ is very small for a lens to be defined as a ScCL and essentially with corneal clearance i.e. the weight is supported by the sclera (scleral bearing) and there is no or minimal contact with the corneal surface (corneal clearance). The larger diameter lenses must be thicker to retain dimensional stability. The central optic zone thickness of the lens depends to some extent on the diameter but more on the optical power, ranging from $0.40 \mathrm{~mm}$ central thickness for high minus powers to almost $2 \mathrm{~mm}$ for very high positive powers. Given these thicknesses, the material used must have the highest possible gas permeability to be effective. The transmission of oxygen depends upon the lens thickness. It may also affect the hypoxia or corneal swelling [37] (Tables $3 \& 4)$.

Some of the past study reveals that the Central Corneal Swelling (CCS) that have been carried out indicate that there is a decreasing return in improvement of corneal metabolism measured by CCS, when the lens thickness is reduced if the material is of a high $\mathrm{Dk}[50,51]$. 


\begin{tabular}{|c|c|c|c|c|}
\hline Author/Journal & Title & Study Design & Sample Size & Findings \\
\hline Shorter E et al. [14] & $\begin{array}{l}\text { Scleral Lenses in the Management } \\
\text { of Corneal Irregularity and Ocular } \\
\text { Surface Disease }\end{array}$ & $\begin{array}{l}\text { SCOPE study group conducted an } \\
\text { electronic survey }\end{array}$ & $\begin{array}{l}\text { 723-providers, who had fit } 5 \text { or } \\
\text { more scleral lenses. 629-Corneal } \\
\text { Irregularity \& 612-OSD }\end{array}$ & $\begin{array}{l}\text { Scleral lenses rank second only to } \\
\text { corneal rigid gas permeable lenses } \\
\text { for management of corneal irregu- } \\
\text { larity. Scleral lenses are generally } \\
\text { considered after other medical } \\
\text { intervention and before surgery for } \\
\text { the management of OSD }\end{array}$ \\
\hline Koppen C et al. [ 38] & $\begin{array}{l}\text { Scleral Lenses Reduce the Need } \\
\text { for Corneal Transplants in Severe } \\
\text { Keratoconus }\end{array}$ & A retrospective case series & 75 -eyes & $\begin{array}{l}\text { Severe keratoconus that would } \\
\text { have undergone transplant surgery } \\
\text { were successfully treated with } \\
\text { long-term scleral lens wear. }\end{array}$ \\
\hline De Luis Eguileor B et al. [39] & $\begin{array}{c}\text { Irregular Corneas: Improve Visual } \\
\text { Function With Scleral Contact } \\
\text { Lenses }\end{array}$ & A prospective study & 15 -eyes (15- patients) & $\begin{array}{l}\text { Both visual acuity and visual } \\
\text { function may improve after fitting } \\
\text { scleral contact lenses in patients } \\
\text { with irregular corneas. These lens- } \\
\text { es can be worn for a longer period } \\
\text { than GP corneal contact lenses. }\end{array}$ \\
\hline Rathi VM et al. [40] & $\begin{array}{l}\text { Role of Scleral Contact Lenses } \\
\text { in Management of Coexisting } \\
\text { Keratoconus and Stevens-Johnson } \\
\text { Syndrome }\end{array}$ & $\begin{array}{l}\text { A retrospective case series (Data } \\
\text { base of 2-year period) }\end{array}$ & 9-eyes (5-patients) & $\begin{array}{l}\text { Keratoconus, a non-inflammatory } \\
\text { condition of the cornea coexisted } \\
\text { with inflammatory SJS. Managing } \\
\text { such patients with ScCLs may } \\
\text { improve vision and comfort. }\end{array}$ \\
\hline Yan P et al. [41] & $\begin{array}{c}\text { Patient comfort and visual } \\
\text { outcomes of mini-scleral contact } \\
\text { lenses }\end{array}$ & A retrospective case series & 40-eyes (32-patients) & $\begin{array}{l}\text { ScCLs may be a comfortable } \\
\text { management option for patients } \\
\text { with keratoconus and other corneal } \\
\text { pathologies, who are unable to } \\
\text { achieve adequate visual outcome } \\
\text { with traditional spectacles or rigid } \\
\text { gas-permeable contact lenses. }\end{array}$ \\
\hline Carracedo G et al. [42] & $\begin{array}{l}\text { Ocular Surface Temperature } \\
\text { During Scleral Lens Wearing in } \\
\text { Patients With Keratoconus }\end{array}$ & $\begin{array}{l}\text { A Pilot, experimental, short-term } \\
\text { study }\end{array}$ & 26-patients & $\begin{array}{l}\text { Scleral contact lens seems not to } \\
\text { modify the ocular surface tempera- } \\
\text { ture despite the presence of the tear } \\
\text { film stagnation under the lens. }\end{array}$ \\
\hline Visser ES et al. [4] & $\begin{array}{l}\text { Modern Scleral Contact Lenses } \\
\text { Part-I: Clinical features }\end{array}$ & A cross-sectional survey & 284 eyes (178-patients) & $\begin{array}{l}\text { Significant increases the monoc- } \\
\text { ular \& binocular VA with scleral } \\
\text { contact lenses }\end{array}$ \\
\hline Pullum K et al. [24] & $\begin{array}{l}\text { Therapeutic and ocular surface in- } \\
\text { dications for scleral contact lenses }\end{array}$ & A review study & Review & $\begin{array}{l}\text { ScCL use valuable and validated } \\
\text { techniques that practitioners } \\
\text { involved with the management } \\
\text { of OSD. }\end{array}$ \\
\hline Pullum K et al. [2] & $\begin{array}{l}\text { Sclera Contact Lens: The Expand- } \\
\text { ing Role }\end{array}$ & A retrospective Review & $\begin{array}{l}1560 \text { eyes (1003-patients) } 1999- \\
2003 .\end{array}$ & $\begin{array}{l}\mathrm{ScCL} \text { continue to play a significant } \\
\text { role in the management of corneal } \\
\text { abnormalities, especially in corneal } \\
\text { transplant and OSD. }\end{array}$ \\
\hline Rosenthal P et al. [18] & $\begin{array}{l}\text { Fluid-ventilated gas permeable } \\
\text { scleral contact lens is an effective } \\
\text { option for managing severe ocular } \\
\text { surface disease and many corneal } \\
\text { disorders that would otherwise } \\
\text { require penetrating keratoplasty }\end{array}$ & A retrospective Review & $\begin{array}{c}\text { 875-eyes (538-patients) past } \\
18 \text {-years }\end{array}$ & $\begin{array}{c}\text { Scleral is an important front-line } \\
\text { tool for managing many corneal } \\
\text { disorders refractory to other treat- } \\
\text { ment measures. }\end{array}$ \\
\hline Smith GT et al. [37] & $\begin{array}{l}\text { Corneal swelling with overnight } \\
\text { wear of scleral contact lenses }\end{array}$ & $\begin{array}{l}\text { 4-patients in one eye only for } \\
\text { 4-ocasions }\end{array}$ & & $\begin{array}{l}\text { There is no adverse effect and } \\
\text { subjects reported \& no difficulties } \\
\text { in handling the lens }\end{array}$ \\
\hline Romero-Rangel T et al. [43] & $\begin{array}{l}\text { Gas-permeable scleral contact lens } \\
\text { therapy in ocular surface disease }\end{array}$ & Review study & 76 eyes (49-patients) & $\begin{array}{l}\text { GP-SCL wear provides an } \\
\text { additional effective strategy in the } \\
\text { surface management and visual re- } \\
\text { habilitation of patients with severe } \\
\text { ocular surface disease. }\end{array}$ \\
\hline
\end{tabular}

Table 3: Scleral Contact Lenses for Treatment of Ocular Surface Disorders: Keratoconus, Irregular Corneas, Corneal Ectasia\& Ocular Surface Disease.

OSD: Ocular Surface Disease, GP-SCL: Gas Permeable Scleral Contact Lens, ScCL: Scleral Contact Lens and SJS: Stevens - Johnson syndrome.

These study result shown that there was no difference in the CCS when the lens thickness was reduced from $0.60 \mathrm{~mm}$ uniformly over the whole optic zone to $0.30 \mathrm{~mm}$ and again to $0.15 \mathrm{~mm}$, which represents a fourfold increase in transmissibility. When a lens with $1.20 \mathrm{~mm}$ uniform optic zone thickness was used, the CCS was more than that induced by the $0.60 \mathrm{~mm}$ thick lens but still considerably less than PMMA. Even a very high positive powered lens is unlikely to exceed
$1.20 \mathrm{~mm}$ average optic zone thickness, so these experimental results should be taken as encouraging [52]. The importance of Dk value in scleral is very significant issues in this practice because this is the directly dependence on a material's oxygen permeable for sclerals [53]. The oxygen permeability (Dk) is measured in units of $x 10^{-11}\left(\mathrm{~cm}^{2} / \mathrm{s}\right)$ $(\mathrm{ml} \mathrm{O} 2 / \mathrm{ml} \mathrm{mm} \mathrm{Hg})$ and Oxygen transmissibility $(\mathrm{Dk} / \mathrm{t})$, where, $\mathrm{t}$ is in $\mathrm{cm}$, is measured in $\times 10^{-9}(\mathrm{~cm} / \mathrm{s})(\mathrm{ml} \mathrm{O} 2 / \mathrm{ml} \mathrm{mm} \mathrm{Hg})$. There is variability in thickness both between different lenses and from point to point 


\begin{tabular}{|c|c|c|c|c|}
\hline Author/Journal & Title & Study Design & Sample Size & Findings \\
\hline Lim Li et al. [16] & $\begin{array}{l}\text { Therapeutic Contact Lenses in the } \\
\text { Treatment of Corneal and Ocular } \\
\text { Surface Diseases }\end{array}$ & A Review Study & Review & $\begin{array}{l}\text { There are many indications and } \\
\text { uses of Therapeutic contact lenses } \\
\text { in alleviating ocular pail, enhanc- } \\
\text { ing corneal healing and corneal } \\
\text { protection. Also, it promising in the } \\
\text { use for drug delivery. }\end{array}$ \\
\hline Yuksel E et al. [44] & $\begin{array}{c}\text { The Management of Refractory } \\
\text { Dry Eye With Semi-Scleral } \\
\text { Contact Lens }\end{array}$ & A review study & Review & $\begin{array}{l}\text { The corneal findings were resolved } \\
\text { and the quality of patient life } \\
\text { was improved with the aid of } \\
\text { semi-scleral lens after } 3 \text { months. }\end{array}$ \\
\hline Jennifer S H et al. [13] & $\begin{array}{l}\text { Therapeutic uses of scleral contact } \\
\text { lenses for ocular surface disease: } \\
\text { patient selection and special } \\
\text { considerations }\end{array}$ & A review study & Review & $\begin{array}{l}\text { Scleral lenses are an effective } \\
\text { therapeutic option in the manage- } \\
\text { ment of ocular surface disease } \\
\text { recalcitrant to traditional therapies. } \\
\text { The overall goal when prescribing } \\
\text { scleral lenses for ocular surface } \\
\text { disease is to improve comfort while } \\
\text { supporting the ocular surface and } \\
\text { improving clinical signs of surface } \\
\text { disease. }\end{array}$ \\
\hline Carracedo $\mathrm{G}$ et al. [45] & $\begin{array}{l}\text { Short-term Effect of Scleral Lens } \\
\text { on the Dry Eye Biomarkers in } \\
\text { Keratoconus }\end{array}$ & $\begin{array}{l}\text { A pilot, experimental\& short-term } \\
\text { study }\end{array}$ & 26-patients & $\begin{array}{l}\text { Short-term scleral lens wearing } \\
\text { improves the symptomatology } \\
\text { and some signs of dry eye, such as } \\
\text { osmolarity and }(\mathrm{Ap}(4) \mathrm{A}) \text { concen- } \\
\text { tration. The increase of MMP-9 } \\
\text { concentration could be caused by } \\
\text { tear film stagnation and use of } \\
\text { preserved saline. }\end{array}$ \\
\hline Guzman A et al. [46] & $\begin{array}{l}\text { Dry Eye Treatment Based on } \\
\text { Contact Lens Drug Delivery }\end{array}$ & A review study & Review & $\begin{array}{l}\text { Contact lenses are emerging as al- } \\
\text { ternative ophthalmic drugs delivery } \\
\text { systems that provide an increased } \\
\text { residence time of the drug at the } \\
\text { eye, thus leading to enhanced bio- } \\
\text { availability and more convenient } \\
\text { and efficacious therapy. }\end{array}$ \\
\hline Bavinger JC et al. [47] & $\begin{array}{l}\text { Scleral lens use in dry eye } \\
\text { syndrome }\end{array}$ & A review study & Review & $\begin{array}{l}\text { Scleral lenses are efficacious and } \\
\text { well tolerated for use in severe dry } \\
\text { eye syndrome. Further research } \\
\text { is needed to compare different } \\
\text { sizes and types of lenses, and to } \\
\text { standardize outcome measures. }\end{array}$ \\
\hline Efron $\mathrm{N}$ et al. [48] & $\begin{array}{l}\text { Contact lens care and ocular } \\
\text { surface homeostasis }\end{array}$ & A review study & Review & $\begin{array}{l}\text { The mucin-glycocalyx plays an im- } \\
\text { portant role in ocular homeostasis. } \\
\text { Tear Osmolarity may be increased } \\
\text { in dry eye diseases \& may ad- } \\
\text { versely affect the tear film and it is } \\
\text { important to prescribed lenses that } \\
\text { will have the least impact possible }\end{array}$ \\
\hline Siqueira AC et al. [49] & $\begin{array}{l}\text { Scleral contact lens for ocular } \\
\text { rehabilitation in patients with } \\
\text { Stevens-Johnson syndrome }\end{array}$ & A retrospective study & 10-eyes (7-patients) & $\begin{array}{l}\text { A successful adaptation to scleral } \\
\text { contact lenses was feasible on most } \\
\text { patients, with relief of symptoms } \\
\text { and better visual acuity. Scleral } \\
\text { contact lenses represent an import- } \\
\text { ant and accessible alternative to } \\
\text { reduce the limitations inferred by } \\
\text { the damages from Stevens-Johnson } \\
\text { syndrome. }\end{array}$ \\
\hline
\end{tabular}

Table 4: Scleral Contact Lenses for Treatment of Ocular Surface Disorder: Dry Eyes, Stevens - Johnson Syndrome and Ocular Surface Homeostasis.

OSD: Ocular Surface Disease, GP-SCL: Gas Permeable Scleral Contact Lens, ScCL: Scleral Contact Lens, SJS: Stevens - Johnson syndrome, MMP-9: Matrix Metallopeptidase-9 and Ap(4)A: Diadenosinetetraphosphate.

on any optically powered lens. The thickest portion of the lens is most important as it is the $\mathrm{Dk} / \mathrm{t}$ at that site, which will produce the greatest hypoxic stress to the underlying corneal tissues [54,55]. Scleral lenses usually trap fluid reservoirs over the corneal surface. The entrapped fluid layer and contact lens should also act as resistance in the two medium as scleral contact lens \& entrapped tear fluid layer. The tear layer creates a surface tension which plays a vital role to supply oxygen for corneal oxygen consumption based on metabolism for living corneal cells $[37,56,57]$.
The potential value of overnight ScCL wear in the management of corneal exposure and some ocular surface diseases has recently been reported by Tappin MJ et al., [58]. The introduction of new rigid gas permeable materials allows oxygen transmission through the lens to the cornea and significantly reduces the corneal hypoxia previously seen with Poly-Methyl-Meth-Acrylate (PMMA) sclerals [50]. As a consequence, the use of RGP ScCLs has increased in recent years both for visual and therapeutic applications. The use of RGP ScCL for daytime wear has considerably reduced central corneal swelling 
compared with that induced by PMMA ScCL and is comparable to physiologic overnight corneal swelling $[59,60]$. The lasting daytime wear benefits of ScCLs sometimes obviate overnight wear of therapeutic lenses. If overnight wear is indicated for therapeutic applications, TSLs are an acceptable option but there are some comprehensible reservations about the use of ScCLs. In major opinion, ScCLs can be considered for overnight wear when continuous corneal hydration or the best possible protection is especially required and this outweighs the anticipated effects of overnight hypoxia and corneal neo-vascularization [57,61-65].

A RGP semi scleral contact lens initially successful fitting for patients with corneal irregularities, who unable conventional contact lenses i.e. corneal contact lenses. This lens appears to increase wearing time, best visual acuity and reduction of other problem commonly related to hypoxia as to compare with corneal lens. Willem et al., [66] reported simply that there was a good correlation between both semi scleral and corneal lens. Semi-scleral lens warranted 0.5 (6/10) SD = 0.28 to $0.7(6 / 8) \mathrm{SD}=0.19$ but this improvement was not significant. However, the visual acuity with semi scleral lens is higher than the patients with the poorer VA with corneal lens. They found in patients wearing semi-scleral lenses with better tolerance \& wearing time of 10-15 hour per day compared with 4-6 hour per day with their corneal lenses. Esther et al., [67] was done another comparative study of visual acuity with scleral lens and without scleral lens, they found median VA with scleral lenses was 0.7 (ranged 0.05 to 1.20 ) and median best corrected VA without a scleral contact lens was 0.2 (ranged 0.003 to 1.00). There was a significant increase in VA with a scleral lens compare to the best corrected VA without a scleral lens is $(\mathrm{P}<0.001)$. This significant value increased in monocular and binocular VA was found with a scleral lens as compared to the best corrected VA without a scleral lens.

Apart from visual improvement, comfort advantages over corneal RGP lenses, they offer a number of applications. However, fitting them has been more art than science. Over the years, the preference has progressed systematically toward larger corneal diameter, then semi-scleral and now scleral lenses. Scleral lenses can be made to completely vault the cornea they are more useful for fragile diseased corneas and for dry eyes. Modern RGP materials cannot be thermoset from impression molds because corneal topographers do not acquire more imaging data information of the sclera, topography is of little use in fitting of these lenses.

\section{Conclusion}

The popularity of scleral lenses continues to grow due to the relative ease of fitting and the potential of giving patients, who have irregular corneas a way to have clear vision without discomfort. With new designs made of high $\mathrm{Dk} / \mathrm{t}$ materials, scleral lenses have demonstrated safe physiological responses for the anterior eye. The novel concept described the tear layers of substantial thicknesses between or under the lenses. It has been well-established that scleral lenses can improve visual acuity in irregular corneal astigmatism and decrease the symptoms associated with ocular surface disorders. The gas permeable scleral lens appears to offer increased wearing time, higher visual acuity and a reduction in other problems commonly related to hypoxia, corneal vascularization and epithelial edema. It is also possible to incorporate almost any power into the scleral lens which enables us to fit patients with very high refractive errors.

\section{The Fine Print}

Scleral lenses rank second only to corneal rigid gas-permeable lenses for management of corneal irregularity. These lenses are generally considered after other medical intervention and before surgery for the management of ocular surface disease.

\section{Acknowledgement and Disclosure}

The authors declare that they do not have any proprietary or financial interest in any of the materials mentioned in this article.

\section{References}

1. Cotter JM, Rosenthal P (1998). Scleral contact lenses. J Am Optom Assoc 69: 33-40.

2. Pullum KW, Whiting MA, Buckley RJ (2005) Scleral contact lenses: The expanding role. Cornea 24: 269-277.

3. Barnett M (2019) Treating ocular surface disease with scleral lenses. Modern Optometry 10: 48-51.

4. Visser ES, Visser R, Van Lier HJ, Otten HM (2007) Modern scleral lenses part I: Clinical features. Eye \& Contact Lens 33: 13-20.

5. Thulasi P, Djalilian AR (2017) Update in Current Diagnostics and Therapeutics of Dry Eye Disease. Ophthalmology 124: 27-33.

6. Sorkin SL (2019) Scleral contact lenses help manage ocular surface disease. Optometry Times 11: 28-29.

7. Craig,JP, Nichols KK, Akpek EK, Caffery B, Dua HS, et al. (2017) TFOS DEWS II definition and classification report. Ocul Surf 15: 276-283.

8. Naeyer GD (2013) Scleral Lenses: An overlooked fix for dry eye? Review of Cornea \& Contact Lens 150: 27-29.

9. Nau CB, Harthan J, Shorter E, Barr J, Nau A, et al. (2018) Demographic characteristics and prescribing patterns of scleral lens fittters: The SCOPE study. Eye \& Contact Lens 1: 265-272.

10. Segal Y Barkana D Hourovitz D, S Behrman, Y Kamun, et al. (2003) Scleral contact lenses may help where other modalities fail. Cornea 22: 308-310.

11. Rosenthal P, Cotter J (2003) The Boston Scleral Lens in the management of severe ocular surface disease. Ophthalmol Clin North Am 16: 89-93.

12. Visser ES, Visser R, Van LHJ (2006) Advantages of toric scleral lenses. Optom Vision Science 83: 233-236.

13. Harthan JS, Shorter E (2018) Therapeutic uses of scleral contact lenses for ocular surface disease: Patient selection and special considerations. Clin Optom (Auckl) 10: 65-74.

14. Shorter E, Harthan J, Nau CB, Nau A, Barr JT, et al. (2018) Scleral Lenses in the Management of Corneal Irregularity and Ocular Surface Disease. Eye Contact Lens 44: 372-378.

15. Schornack MM, Pyle J, Patel SV (2014) Scleral lenses in the management of ocular surface disease. Ophthalmology 121: 1398-1405.

16. Lim L, Lim E, Ling W (2020) Therapeutic Contact Lenses in the Treatment of Corneal and Ocular Surface Diseases. Asia Pac J Ophthalmology 9: 524-532.

17. Foss AJE, Trodd TC, Dart JKG (1994) Current indications for scleral contact lenses. CLAO 20: 115-118.

18. Rosenthal P, Croteau A (2005) Fluid-ventilated, gas-permeable scleral contact lens is an effective option for managing severe ocular surface disease and many corneal disorders that would otherwise require penetrating keratoplasty. Eye \& Contact Lens 31: 130-134.

19. Pullum KW (2007) Scleral contact lenses. In: Phillips AJ, Speedwell L (eds.). Contact lenses. Elsevier Science, Oxford, UK. 
20. Pullum KW (1999) The unique role of scleral lenses in contact lens practice. Cont Lens Anterior Eye 22: S26-S34.

21. Schein OD, Rosenthal P, Ducharme C (1990) A gas-permeable scleral contact lens for visual rehabilitation. Am. J Ophthalmol 109: 318-322.

22. Rabinowitz YS (1998) Keratoconus: Major review. Surv Ophthalmol 42: 297-319.

23. Peng CC, Burke MT, Carbia BE, Plummer C, Chauhan A (2012) Extended drug delivery by contact lenses for glaucoma therapy. J Control Release 162: $152-158$

24. Pullum KW, Buckley R (2007) Therapeutic and Ocular Surface Indications for Scleral Contact Lenses. Ocul Surf 5: 40-49.

25. Michaud L, Lipson M, Kramer E, Walker M (2020) The official guide to scleral lens terminology. Cont Lens Anterior Eye 43: 529-534.

26. Van der Worp E (2015) A guide to scleral lens fitting, version 2.0 (monograph online). Forest Grove, OR: Pacific University.

27. Official terminology related to scleral lenses, Scleral Lens Education Society.

28. Schornack MM, Baratz KH, Patel SV, Maguire LJ (2008) Jupiter sclera lenses in the management of chronic graft versus host disease. Eye Contact Lens 34: 302-305

29. Van der Worp E, Bornman D, Ferreira DL, Faria-Ribeiro M, Garcia-Porta N, et al. (2014) Modern scleral contact lenses: A review. Cont Lens Anterior Eye 37: 240-250.

30. Jedlicka J, Johns LK, Byrnes SP (2010) Scleral Contact Lens Fitting Guide; Contact Lens Spectrum 1-11.

31. McMahon J (2011) Scleral contact lenses and their therapeutic uses Part-I (Module-C16806), Optician 32-37.

32. McMohan J (2011) Scleral contact lenses and their therapeutic uses Part-II (Module-C16965), Optician 30-33

33. Ezekiel D (1983) Gas Permeable Haptic (GPH) lenses. J Br Contact Lens Assoc 6: 158-161

34. Tan DT, Pullum KW, Buckley RJ (1995) Medical applications of scleral contact lenses: A retrospective analysis of 343 cases. Cornea 14: 121-129.

35. Tan DT, Pullum KW, Buckley RJ (1995b). Medical applications of scleral contact lenses: Gas permeable scleral contact lenses. Cornea 14: 130-137.

36. Kok JH, Visser R (1992) Treatment of ocular disorders and dry eyes with high gas-permeable scleral lenses. Cornea 11: 518-522.

37. Smith GT, Mireskandari K, Pullum KW (2004) Corneal swelling with overnight wear of scleral contact lenses. Cornea 23: 29-34.

38. Koppen C, Kreps EO, Anthonissen L, Van Hoey M, Dhubhghaill SN, et al. (2018) Scleral lenses reduce the need for corneal transplants in severe keratoconus. Am J Ophthalmol 185: 43-47.

39. de Luis Eguileor B, Ecenarro JE, Carro AS, Lera RF (2018) Irregular Corneas: Improve visual function with scleral contact lenses. Eye Contact Lens 44: 159-163.

40. Rathi VM, Taneja M, Dumpati S, Mandathara PS, Sangwan VS (2017) Role of Scleral Contact Lenses in Management of Coexisting Keratoconus and Stevens-Johnson Syndrome. Cornea 36: 1267-1269.

41. Yan P, Kapasi M, Conlon R, Teichman JC, Yeung S, et al. (2017) Patient comfort and visual outcomes of mini-scleral contact lenses. Can J Ophthalmol 52: 69-73.

42. Carracedo G, Wang Z, Serramito-Blanco M, Martin-Gil A, Carballo-Alvarez J, et al. (2017) Ocular surface temperature during scleral lens wearing in patients with keratoconus. Eye Contact Lens 43: 346-351.

43. Romero-Rangel T, Stavrou P, Cotter JM, Rosenthal P, Baltatzis S, et al (2000) Gas-permeable scleral contact lens therapy in ocular surface disease. Am J Ophthalmology 130: 25-32.
44. Yuksel E, Bilgihan K, Novruzlu S, Yuksel N, Koksal M (2018) The management of refractory dry eye with Semi-scleral contact lens. Eye Contact Lens 44: e10-e12.

45. Carracedo G, Blanco MS, Martin-Gil A, Zicheng W, Alvarez JC, et al. (2016) Short-term effect of Scleral lens on the dry eye biomarkers in keratoconus. Optom Vis Sci 93: 150-157.

46. Guzman-Aranguez A, Fonseca B, Carracedo G, Martin-Gil A, Martinez-Aguila A, et al. (2016) Dry eye treatment based on contact lens drug delivery: A Review. Eye Contact Lens 42: 280-288.

47. Bavinger JC, DeLoss K, Mian SI (2015) Scleral lens use in dry eye syndrome. Curr Opin Ophthalmol 26: 319-324.

48. Efron N, Brennan NA, Bright FV, Glasgow BJ, Jones LW, et al. (2013) Contact lens care and ocular surface homeostasis. Cont Lens Anterior Eye 36: S9-S13.

49. Siqueira AC, Santos MS, Farias CC, Barreiro TR, Gomes JÁ (2010) Scleral contact lens for ocular rehabilitation in patients with Stevens-Johnson Syndrome. Arq Bras Ophthalmol 73: 428-432.

50. Pullum KW, Hobley AJ, Parker JH (1990) Hypoxic corneal changes following sealed gas permeable impression scleral lens wear. Dallos Award Lecture Part-II. J Br Contact Lens Assoc 13: 83-87.

51. Pullum KW, Stapleton FJ (1997) Scleral lens-induced corneal swelling: what is the effect of varying Dk and lens thickness? CLAO 23: 259-63.

52. Pullum KW, Hobley AJ, Davison C (1991) 100'Dk: Does thickness make much difference? J Br Contact Lens Assoc 6: 158-161.

53. Refojo MF (1984) The siloxane bond in contact lens materials: Effect of methyl and phenyl content on oxygen permeability of silicone lenses. ICLC 11: 83-86.

54. Holden BA, Mertz GW (1984) Critical oxygen levels to avoid corneal edema for daily and extended wear contact lenses. Invest Ophthalmol Vision Science 25: 1161-1167.

55. Holden BA, Sweeney DF, Sanderson G (1984) The minimum pre corneal oxygen tension to avoid corneal oedema. Invest. Ophthalmol. Vision Science 25: 476-480.

56. Weissman BA, Ye P (2006) Calculated tear oxygen tension under contact lenses offering resistance in series: Piggyback and scleral lenses. Contact Lens \& Anterior Eye 29: 231-237.

57. Sarver MD, Polse KA, Baggett DA (1983) Inter-subject difference in corneal oedema response to hypoxia. Am J Optom Physiol Opt 60: 128-131.

58. Tappin MJ, Pullum KW, Buckley RJ (2001) Scleral contact lenses for overnight wear in the management of ocular surface disorders. Eye 15: 168-172.

59. Mertz GW (1980) Overnight swelling of the living human cornea. J Am Optom Assoc 51: 211-213.

60. Starmann MT, Schoessler JP (1991) Contact lenses and eye closure: comparative analysis using three different methods to induce corneal swelling. Optom Vision Science 68: 374-379.

61. Fatt I, Chaston J (1982) Relation of Oxygen Transmissibility to Oxygen Tension or EOP under the lens. ICLC 9: 119-120.

62. Bleshoy, Pullum KW (1988) Corneal response to gas permeable impression scleral lenses. J Br Contact Lens Assoc 11: 31-34.

63. Vanessa B, Stefano F, Adriano F, Emilio P, Giorgio M, et al. (2010) Evaluation of ocular surface disorders: A new diagnostic tool based on impression cytology and confocal laser scanning microscopy. Br J Ophthalmol 94: 926-932.

64. Alex J S, Genevieve AS, Peterm M, Peng T K, Stephen JT, et al. (2007) Characterization of the Limbal Epithelial Stem Cell Niche: Novel Imaging Techniques Permit In Vivo Observation and Targeted Biopsy of Limbal Epithelial Stem Cells. Stem Cells 25: 1402-1409.

65. Gemoules G (2008) A novel method of fitting scleral lenses using high resolution optical coherence tomography. Eye \& Contact Lens 34: 80-83. 
Citation: Sah R, Titiyal JS (2021) Scleral Contact Lenses for Treatment of Ocular Surface Disorders: A Narrative Review. J Ophthalmic Clin Res 8: 086.

- Page 8 of 8 -

66. Vreugdenhil W, Geerards AJ, Vervaet CJ (1998) A new rigid gas-permeable semi-scleral contact lens for treatment of corneal surface disorders. Contact Lens \& Anterior Eye 21: 85-88.
67. Visser E-S, Visser R, Lier HJJ, Otten HM (2007) Modern Scleral Lenses Part I: Clinical Features. Eye \& Contact Lens 733: 13-20. 


\section{H \\ .}

Advances In Industrial Biotechnology | ISSN: 2639-5665

Advances In Microbiology Research | ISSN: 2689-694X

Archives Of Surgery And Surgical Education | ISSN: 2689-3126

Archives Of Urology

Archives Of Zoological Studies | ISSN: 2640-7779

Current Trends Medical And Biological Engineering

International Journal Of Case Reports And Therapeutic Studies | ISSN: 2689-310X

Journal Of Addiction \& Addictive Disorders | ISSN: 2578-7276

Journal Of Agronomy \& Agricultural Science | ISSN: 2689-8292

Journal Of AIDS Clinical Research \& STDs | ISSN: 2572-7370

Journal Of Alcoholism Drug Abuse \& Substance Dependence | ISSN: 2572-9594

Journal Of Allergy Disorders \& Therapy | ISSN: 2470-749X

Journal Of Alternative Complementary \& Integrative Medicine | ISSN: 2470-7562

Journal Of Alzheimers \& Neurodegenerative Diseases | ISSN: 2572-9608

Journal Of Anesthesia \& Clinical Care | ISSN: 2378-8879

Journal Of Angiology \& Vascular Surgery | ISSN: 2572-7397

Journal Of Animal Research \& Veterinary Science | ISSN: 2639-3751

Journal Of Aquaculture \& Fisheries | ISSN: 2576-5523

Journal Of Atmospheric \& Earth Sciences | ISSN: 2689-8780

Journal Of Biotech Research \& Biochemistry

Journal Of Brain \& Neuroscience Research

Journal Of Cancer Biology \& Treatment | ISSN: 2470-7546

Journal Of Cardiology Study \& Research | ISSN: 2640-768X

Journal Of Cell Biology \& Cell Metabolism | ISSN: 2381-1943

Journal Of Clinical Dermatology \& Therapy | ISSN: 2378-8771

Journal Of Clinical Immunology \& Immunotherapy | ISSN: 2378-8844

Journal Of Clinical Studies \& Medical Case Reports | ISSN: 2378-8801

Journal Of Community Medicine \& Public Health Care | ISSN: 2381-1978

Journal Of Cytology \& Tissue Biology | ISSN: 2378-9107

Journal Of Dairy Research \& Technology | ISSN: 2688-9315

Journal Of Dentistry Oral Health \& Cosmesis | ISSN: 2473-6783

Journal Of Diabetes \& Metabolic Disorders | ISSN: 2381-201X

Journal Of Emergency Medicine Trauma \& Surgical Care | ISSN: 2378-8798

Journal Of Environmental Science Current Research | ISSN: 2643-5020

Journal Of Food Science \& Nutrition | ISSN: 2470-1076

Journal Of Forensic Legal \& Investigative Sciences | ISSN: 2473-733X

Journal Of Gastroenterology \& Hepatology Research | ISSN: 2574-2566
Journal Of Genetics \& Genomic Sciences | ISSN: 2574-2485

Journal Of Gerontology \& Geriatric Medicine | ISSN: 2381-8662

Journal Of Hematology Blood Transfusion \& Disorders | ISSN: 2572-2999

Journal Of Hospice \& Palliative Medical Care

Journal Of Human Endocrinology | ISSN: 2572-9640

Journal Of Infectious \& Non Infectious Diseases | ISSN: 2381-8654

Journal Of Internal Medicine \& Primary Healthcare | ISSN: 2574-2493

Journal Of Light \& Laser Current Trends

Journal Of Medicine Study \& Research | ISSN: 2639-5657

Journal Of Modern Chemical Sciences

Journal Of Nanotechnology Nanomedicine \& Nanobiotechnology | ISSN: 2381-2044 Journal Of Neonatology \& Clinical Pediatrics | ISSN: 2378-878X

Journal Of Nephrology \& Renal Therapy | ISSN: 2473-7313

Journal Of Non Invasive Vascular Investigation | ISSN: 2572-7400

Journal Of Nuclear Medicine Radiology \& Radiation Therapy | ISSN: 2572-7419

Journal Of Obesity \& Weight Loss | ISSN: 2473-7372

Journal Of Ophthalmology \& Clinical Research | ISSN: 2378-8887

Journal Of Orthopedic Research \& Physiotherapy | ISSN: 2381-2052

Journal Of Otolaryngology Head \& Neck Surgery | ISSN: 2573-010X

Journal Of Pathology Clinical \& Medical Research

Journal Of Pharmacology Pharmaceutics \& Pharmacovigilance | ISSN: 2639-5649

Journal Of Physical Medicine Rehabilitation \& Disabilities | ISSN: 2381-8670

Journal Of Plant Science Current Research | ISSN: 2639-3743

Journal Of Practical \& Professional Nursing | ISSN: 2639-5681

Journal Of Protein Research \& Bioinformatics

Journal Of Psychiatry Depression \& Anxiety | ISSN: 2573-0150

Journal Of Pulmonary Medicine \& Respiratory Research | ISSN: 2573-0177

Journal Of Reproductive Medicine Gynaecology \& Obstetrics | ISSN: 2574-2574

Journal Of Stem Cells Research Development \& Therapy | ISSN: 2381-2060

Journal Of Surgery Current Trends \& Innovations | ISSN: 2578-7284

Journal Of Toxicology Current Research | ISSN: 2639-3735

Journal Of Translational Science And Research

Journal Of Vaccines Research \& Vaccination | ISSN: 2573-0193

Journal Of Virology \& Antivirals

Sports Medicine And Injury Care Journal | ISSN: 2689-8829

Trends In Anatomy \& Physiology | ISSN: 2640-7752

Submit Your Manuscript: https://www.heraldopenaccess.us/submit-manuscript 